\title{
Steel corrosion in reinforced alkali-activated materials
}

\author{
Shishir Mundra ${ }^{a}$, Susan A. Bernal ${ }^{a}$, Maria Criado ${ }^{a}$, Petr Hlaváček ${ }^{b}$, Gino Ebell ${ }^{b}$, Steffi Reinemann ${ }^{b}$, Gregor \\ J. G. Gluth ${ }^{\mathrm{b}}$, John L. Provis ${ }^{\mathrm{a} *}$
}

\footnotetext{
a Department of Materials Science and Engineering, The University of Sheffield, Sir Robert Hadfield Building, Sheffield, S1 3JD, United Kingdom

${ }^{b}$ Bundesanstalt für Materialforschung und -prüfung (BAM), Unter den Eichen 87, 12205 Berlin, Germany
}

Received: 29 October 2017 / Accepted: 8 December 2017 / Published online: 18 December 2017

(C) The Author(s) 2017. This article is published with open access and licensed under a Creative Commons Attribution 4.0 International License.

\begin{abstract}
The development of alkali-activated materials (AAMs) as an alternative to Portland cement (PC) has seen significant progress in the past decades. However, there still remains significant uncertainty regarding their long term performance when used in steel-reinforced structures. The durability of AAMs in such applications depends strongly on the corrosion behaviour of the embedded steel reinforcement, and the experimental data in the literature are limited and in some cases inconsistent. This letter elucidates the role of the chemistry of AAMs on the mechanisms governing passivation and chloride-induced corrosion of the steel reinforcement, to bring a better understanding of the durability of AAM structures exposed to chloride. The corrosion of the steel reinforcement in AAMs differs significantly from observations in PC; the onset of pitting (or the chloride 'threshold' value) depends strongly on the alkalinity, and the redox environment, of these binders. Classifications or standards used to assess the severity of steel corrosion in PC appear not to be directly applicable to AAMs due to important differences in pore solution chemistry and phase assemblage.
\end{abstract}

Keywords: Alkali-activated materials; Corrosion; Chloride; Redox processes

\section{Introduction}

Alkali-activated materials (AAMs) are the products of the reaction between an aluminosilicate source (usually industrial by-products such as slags from the iron and steel industry, coal fly ashes from thermoelectric plants, among others) and an aqueous 'activator', which supplies alkaline constituents, usually alkali-metal hydroxide, silicate, carbonate or sulfate [1,2]. AAMs can be broadly categorised into systems with high Ca content, such as alkali-activated slags, where the phase assemblage is dominated by a calcium-aluminosilicate hydrate (C-A-S-H) type gel; and low Ca systems such as alkali-activated fly ashes, where the main reaction product is a three-dimensional alkali-aluminosilicate hydrate (N-A-S-H) type gel [3-5]. AAMs offer the possibility of achieving significant reductions in greenhouse emissions, while achieving mechanical properties comparable to those of Portland cement (PC) [6,7]. The reaction products, the pore network microstructure and the pore solution composition in AAMs vary significantly from those encountered in PC-based binders [5,8]. However, within the class of materials referred to as AAMs, these same characteristics also vary significantly depending on the precursor chemistry, and the type and amount of activating solution used for their production [3,8]. Therefore, mechanisms of steel reinforcement corrosion in AAMs, either due to lowering of the $\mathrm{pH}$ due to carbonation, or due to chloride ingress, can differ from those typically identified in PC-based materials [9-11].

The service life of a steel-reinforced concrete structure under exposure conditions which induce the corrosion of its reinforcement can be described conceptually according to the model proposed by Tuutti, which is characterised by the initiation phase, the onset of corrosion, and the propagation phase [12]. Given the differences in pore solution chemistry and phase assemblage between AAMs and PC, both the initiation and propagation timescales in a service life model are expected to be different. Studies concerning durability of AAMs in the presence of chlorides have mainly centred on determining transport properties such as water and chloride permeability parameters $[13,14]$, but the focus of this letter is on a much less-studied question: what are the conditions required for the onset of chloride-induced steel corrosion in AAMs, once the chloride has passed through the cover concrete and begun to increase in concentration at the steelconcrete interface $(\mathrm{SCl})$ ? The definition of the 'onset' of corrosion in concrete structures has often been considered to be linked to the existence of a chloride 'threshold' value or the minimum concentration of chloride required at the $\mathrm{SCl}$ for depassivation of the steel reinforcement [15]. As is 
the case for $\mathrm{PC}$, the available data on the chloride threshold value for various AAMs are very scattered, which makes it very difficult to assertively draw conclusions regarding their likely duration of serviceability.

To work toward resolving this question, this letter provides new insight into the mechanisms governing passivation and the onset of chloride-induced corrosion of the steel reinforcement in AAMs, and proposes a new approach for classifying AAMs according to their internal redox chemistry, when considering the likely durability of steel rebars embedded in such materials in the presence of chloride.

\section{Binders with an oxidising internal environment}

In the absence of any aggressive species, cementitious binders generally provide a highly alkaline and weakly oxidative environment, enabling mild steel reinforcement to remain in a passive state. Low Ca AAMs such as alkaliactivated fly ashes and alkali-activated metakaolin also fall into this category, where the main reaction product is dominated by a highly crosslinked three dimensional alkalialuminosilicate hydrate (N-A-S-H) type gel, which may contain some crystalline zeolites. The pore solutions of these binders are highly alkaline ( $\mathrm{pH} 13.5$ to 14 or more), and are generally characterised by very high concentrations of $\mathrm{Na}^{+}$ and $\mathrm{OH}^{-}$, in the range of $0.60 \mathrm{M}$ to $1.60 \mathrm{M}$ [16]. The concentrations of $\mathrm{Al}, \mathrm{Si}$, and $\mathrm{Ca}$ have been found to be close to or less than $1 \mathrm{mM}[16,17]$. The presence of sulfate in the pore solutions of these AAMs has not been reported in the literature, but will be determined in large part by the composition of the raw materials used, as there are no identified sulfate-containing reaction products in lowcalcium AAMs.

Steel embedded in binders based on alkali-activated fly ash or metakaolin appear to follow similar passivation mechanisms to that observed in PC, due to the similar oxidising capabilities of the pore solutions in these cements. The passive film on the steel reinforcement in PC and in alkali-activated fly ash or metakaolin can be described as a complex assemblage of iron oxides, with the inner layer being a dense $\mathrm{Fe}$ (II, III) oxide, surrounded by an outer layer of a hydrated Fe(III) oxide [10]. Several studies [18-20] have observed very similar passivation mechanisms of steel rebars embedded in PC and in alkali-activated fly ash, and reported values of the corrosion potential and current density $\left(E_{\text {corr }}\right.$ and $\left.i_{\text {corr }}\right)$ ranging from 0.05 to $-0.20 \mathrm{~V} \mathrm{vs}$. $\mathrm{Ag} / \mathrm{AgCl}$, and $10^{-1}$ to $10^{-3} \mu \mathrm{A} / \mathrm{cm}^{2}$, respectively. In some cases [21], the steel embedded in alkali-activated fly ash was observed to be more resistant to corrosion than in PC, which was attributed to the inhibitive properties of soluble silicates in the pore solution of the alkali-activated binders. Conversely, Hlaváček et al. [22] identified a delay in the development of a passive film for steel embedded in alkali-activated fly ash mortars when compared to PC mortars, when a continuous assessment of $E_{\text {corr }}$ was carried out (Fig.1). This trend was also identified via measurement of polarisation resistance $\left(R_{p}\right)$, using galvanostatic pulse measurements (Fig.1). Other studies also report $E_{\text {corr }}[23,24]$ values for the embedded steel in the passive state to be much lower in alkali-activated fly ash than is generally observed in PC. However, these electrochemical observations do not necessarily indicate that the steel is more susceptible to chloride-induced corrosion when embedded in alkali-activated fly ashes, as these results may indicate a lower availability of oxygen at the $\mathrm{SCl}$. Additionally, the lower resistivities of the alkaliactivated fly ashes in comparison to PC (expressed as ohmic resistance $\left(R_{e l}\right)$ in Fig.1), do not indicate a higher susceptibility of the steel to corrosion, and instead, are due to the very high ionic strength of the pore solution [16] and the more open pore structure in such systems [14].

Most studies on chloride-induced corrosion of steel in lowCa AAMs have been based on the treatment of chloride as an 'admixture' included during the mixing process of the binder, rather than exposing the material to an external chloride source [18-20,25]; and the onset of corrosion in some studies [25] was found to occur when the concentration of chloride in the binder was $0.4 \mathrm{wt} . \%$ of binder. Monticelli et al. [21], on the other hand, found chloride 'threshold' values for alkali-activated fly ashes (1 1.7 wt.\% of binder) that were significantly higher than those observed for PC ( 0.5 wt.\% of binder).
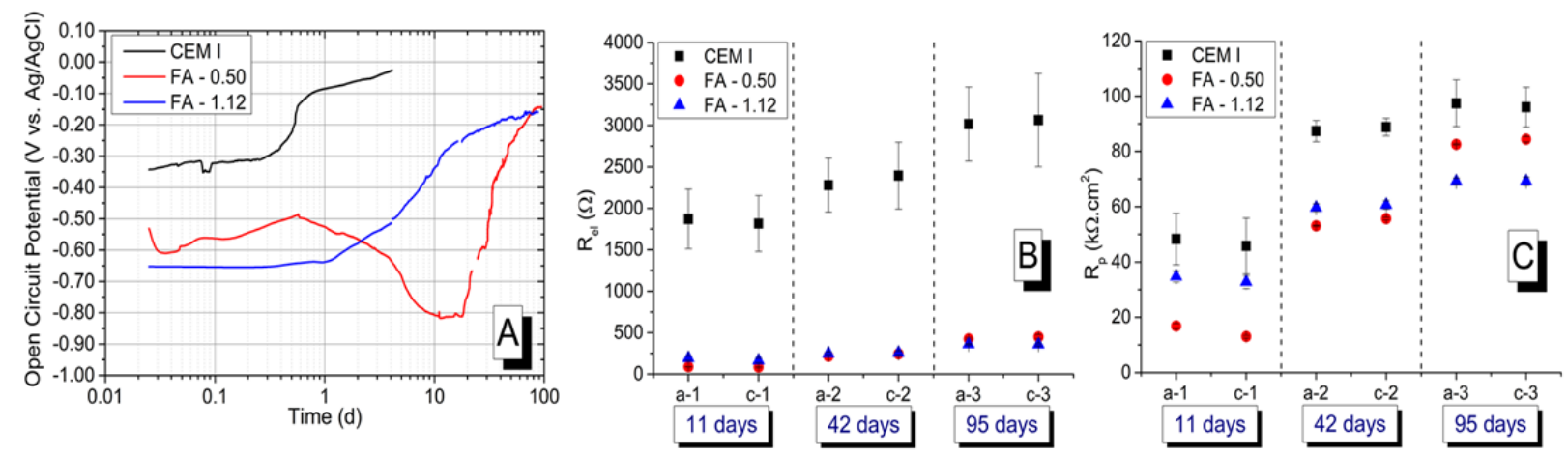

Figure 1. (A) Open circuit potential (V vs. $\mathrm{Ag} / \mathrm{AgCl})$, (B) ohmic resistance $\left(R_{e l}\right)$ and $(\mathrm{C})$ polarisation resistance $\left(R_{p}\right)$ as a function of time for steel embedded in mortars of CEM I, fly ash activated by sodium silicate solution with a modulus (molar ratio $\mathrm{SiO}_{2} / \mathrm{Na}_{2} \mathrm{O}$ ) of $0.50(\mathrm{FA}-0.50$ ), and fly ash activated by sodium silicate solution with a modulus of 1.12 (FA-1.12). The $R_{e l}$ and $R_{p}$ values were measured using the galvanostatic pulse technique after $11(a-1, c-1), 42(a-2, c-2)$ and $95(a-3, c-3)$ days. The annotations ' $a$ ' and ' $c$ ' denote the anodic and cathodic pulses, respectively. 

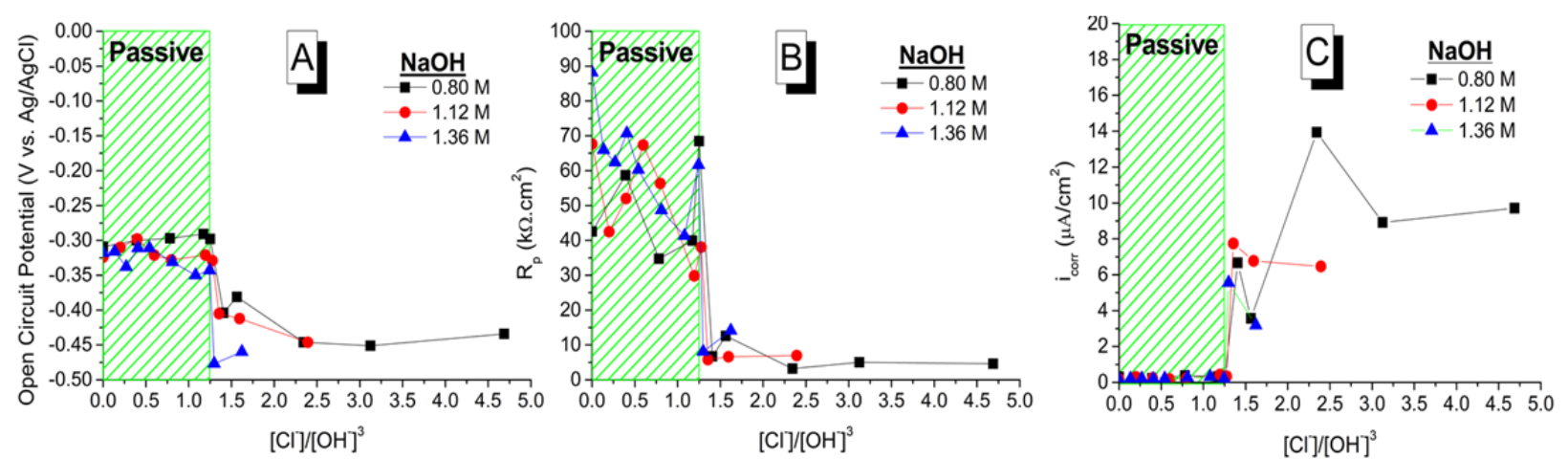

Figure 2. (A) Open circuit potential, (B) $R_{p}$, and (C) $i_{\text {corr }}$ as a function of $\left[\mathrm{Cl}^{-}\right] /\left[\mathrm{OH}^{-}\right]^{3}$, for steel rebars immersed in simulated pore solutions of low$\mathrm{Ca}$ AAMs with varying $\mathrm{NaOH}$ concentrations. The green dashed area indicates the region where the steel remains passive for $\left[\mathrm{Cl}^{-}\right] /\left[\mathrm{OH}^{-}\right]^{3}<1.25$. (adapted from [10]).

The clear inconsistency of results among different studies elucidates that different factors such as chemistry of the fly ash and the activator used to produce these binders, as well as curing conditions and other factors, can strongly influence the interaction of chloride with embedded steel reinforcement in alkali-activated binders.

In a recent study [10] conducted in simulated pore solutions representative of low-Ca AAMs, the alkalinity of the pore solution at the $\mathrm{SCl}$ was found to have a significant influence on the chloride 'threshold' value - very similar to observations in pore solutions of $\mathrm{PC}$, but with observed initiation only at much higher $\left[\mathrm{Cl}^{-}\right] /\left[\mathrm{OH}^{-}\right]$ratios in these highly alkaline simulated pore solutions. It is important to mention that unlike PC, alkali-activated binders in general do not form $\mathrm{Ca}(\mathrm{OH})_{2}$ that can act as a $\mathrm{pH}$ buffer, and so any loss in alkalinity due to leaching or carbonation cannot be compensated by any of the reaction products formed in these binders. Therefore, the onset of pitting depends strongly on the ability to retain the alkalinity of the pore solution at the $\mathrm{SCl}$ (through curing to achieve a refined pore structure, and formulation to minimise porosity), as well as the local chloride concentration. It was determined in [10] that the onset of pitting in these highly alkaline binders can be predicted by a relationship involving $\left[\mathrm{Cl}^{-}\right] /\left[\mathrm{OH}^{-}\right]^{3}$ rather than a direct ratio of these quantities, where a value of $[\mathrm{Cl}] /\left[\mathrm{OH}^{-}\right]^{3}<1.25$ at the $\mathrm{SCl}$ would enable the steel reinforcement to be in the passive state while immersed in highly concentrated $\mathrm{NaOH}$, while any value above 1.25 would indicate pitting (stable or metastable) of the steel (Fig.2). Once pitting has initiated and a local acidification has occurred, repassivation of the pit in the absence of $\mathrm{Ca}(\mathrm{OH})_{2}$ would be solely reliant on the concentration of $\left[\mathrm{OH}^{-}\right]$around the pit.

In the case of AAMs exhibiting an oxidising environment such as in alkali-activated fly ash, Babaee and Castel [23] showed that the proportionality constant $B$, used in the modified Stern-Geary equation to calculate the corrosion rates, deviates significantly from those used in PC-based concretes. It was observed [23] that using conventional values [26] of $B=52$ (passive state) and $B=26$ (active state) for steel-reinforced alkali-activated fly ash concretes yields an overestimation of the corrosion current density in the passive state, but an underestimation in the active state. This was consistent with the calculation of $i_{\text {corr }}$ values for steel immersed in simulated pore solutions of low-Ca AAMs [10]. Therefore, further attention must be paid to the validation of appropriate $B$ values for these binders, to avoid discrepancies in predicting their service life. Similarly, analysing $E_{\text {corr }}$ and $i_{\text {corr }}$ values according to recommendations or classifications set for PC based concretes (ASTM C876-15 [27] and [28]) to characterise the passive or the active state would be misleading in the case of these binders, as the ionic strength, diffusivity and pore solution composition are very different from the conditions prevailing inside PC.

\section{Binders with a reducing internal environment}

Modern construction relies on the use of ground granulated blast furnace slag (GGBS) as a supplementary cementitious material. The reducing nature of the blast furnace is retained by the slag, which contains $1-2$ wt.\% sulfur, mostly in a reduced state and available to dissolve when mixed with PC and water. Vollpracht et al. [29] reported aqueous sulfur in the pore solutions of PC-GGBS blends to be in various oxidation states such as $\mathrm{HS}^{-}, \mathrm{S}_{\mathrm{n}}{ }^{2-}, \mathrm{SO}_{3}{ }^{2-}, \mathrm{S}_{2} \mathrm{O}_{3}{ }^{2-}$, and $\mathrm{SO}_{4}{ }^{2-}$. Several studies [30-32] report that between $30-80 \%$ of the total sulfur in the pore solutions of hydrated PC-GGBS blends is in a reduced state $\left(\mathrm{HS}^{-}, \mathrm{S}_{\mathrm{n}}{ }^{2-}, \mathrm{SO}_{3}{ }^{2-}\right.$ or $\left.\mathrm{S}_{2} \mathrm{O}_{3}{ }^{2-}\right)$, depending on GGBS content and the degree of hydration. This creates a highly reducing environment at the $\mathrm{SCl}[12,30,32,33]$ and also leads to a decrease in the amount of dissolved oxygen within the pore solution [32].

In alkali-activated slags (AAS), where GGBS is used as the main precursor and activated by a highly alkaline solution, the presence of reduced sulfur species in the pore solutions also yields a highly reducing pore solution environment [34]. The phase assemblage in AAS is predominantly C-A-S-H type gels, with secondary reaction products including hydrotalcite-like Mg-Al layered double hydroxides (LDH) depending on the Mg content of the slag $[1,3,35,36]$.

The pore solutions of AAS are characterised by significant concentrations of alkali-metal cations ( $\mathrm{Na}$ ) due to the activator, much higher than concentrations of $\mathrm{K}$ and $\mathrm{Na}$ in PC-GGBS blends, and extremely high alkalinity $(13 \leq \mathrm{pH} \leq$ 
14.2). The concentrations of $\mathrm{Al}, \mathrm{Si}$ and $\mathrm{Ca}$ in the pore solutions of AAS are similar to those of PC-GGBS blends, and somewhat lower than those of plain PC. One of the more noticeable differences between the pore solutions of PCGGBS blends and AAS is the higher concentration of reduced sulfur species in the latter (to which the 'blue-green' colour of AAS [37] is attributed). Gruskovnjak et al. [38] measured, and Myers et al. [34,39] thermodynamically calculated, the concentration of reduced sulfur species (mainly HS') in AAS to be around $\sim 0.45 \mathrm{M}$. However, given the strong tendency of $\mathrm{HS}^{-}$to undergo oxidation, the presence of thiosulfate $\left(\mathrm{S}_{2} \mathrm{O}_{3}{ }^{2-}\right)$, sulfite $\left(\mathrm{SO}_{3}{ }^{2-}\right)$, polysulfide $\left(\mathrm{S}_{\mathrm{n}}{ }^{2-}\right)$ and sulfate $\left(\mathrm{SO}_{4}{ }^{2-}\right)$ anions in trace quantities within the pore solution is inevitable [38,40].

As in PC-GGBS blends [32], the presence of a reductant in the pore solution will influence the passivation of steel reinforcement, and also its breakdown due to the presence of chloride at the $\mathrm{SCl}$. With such high concentrations of $\mathrm{HS}^{-}$in AAS pore solutions, the amount of dissolved oxygen near the $\mathrm{SCl}$ can be expected to be lower than in PC and in PC-GGBS blends [32], driving the redox potential of the embedded steel reinforcement towards more negative values than is generally observed in the passive state in oxidising binders. This was confirmed by Holloway and Sykes [41] and by Criado et al. [42], where $E_{\text {corr }}$ values for steel embedded in AAS were found to be between -0.45 and $-0.60 \mathrm{~V}$ vs. $\mathrm{Ag} / \mathrm{AgCl}$. The reducing conditions at the $\mathrm{SCl}$ in AAS would favour the iron being in the reduced $\mathrm{Fe}^{2+}$ state, rather than the more usual $\mathrm{Fe}^{3+}$ state found in passivating oxide films in oxidising binders.

In highly alkaline sulfide-containing solutions, competitive adsorption processes involving $\left[\mathrm{OH}^{-}\right]_{\mathrm{ads}}$ and $\left[\mathrm{HS}^{-}\right]_{\mathrm{ads}}$ retard and inhibit the development of an iron oxide passive film, and can instead lead to the precipitation of mackinawite $\left(\mathrm{Fe}_{1+x} \mathrm{~S}\right)$ on the steel surface [43-45]. Fig.3 shows two cyclic voltammograms depicting the influence of sulfide on the passivation behaviour of steel in highly alkaline solutions. Fig.3A shows a typical cyclic voltammogram obtained for mild steel in alkaline solutions $\left(0.80 \mathrm{M} \mathrm{OH}^{-}\right.$in this case) and the passive film formed under such conditions has been described in detail in [10]. Fig.3B shows the influence of the presence of sulfide in the solution $\left(0.80 \mathrm{M} \mathrm{OH}^{-}+0.45 \mathrm{M} \mathrm{HS}^{-}\right.$ in this case) on steel passivation. The high concentration of $\mathrm{HS}^{-}$in the pore solution of AAS clearly alters the chemistry of the surface film, which in this case is primarily composed of $\mathrm{Fe}^{2+}$ species, with the inner layer being $\mathrm{Fe}(\mathrm{OH})_{2}$ (that could potentially oxidise to a hydrated $\mathrm{Fe}^{3+}$ oxide if sufficient oxygen is available at later stages) and the outer layer being a Fe-S complex, possibly resembling disordered mackinawite.

Given the difference in the steel surface encountered in AAS compared to steel in oxidising $\mathrm{SCl}$ environments, the resistance to chloride-induced corrosion of these binders would also be expected to differ. Holloway and Sykes [41] studied the corrosion behaviour of steel in AAS mortars containing admixed chloride, and did not observe welldefined trends for either $i_{\text {corr }}$ and $E_{\text {corr }}$ as a function of the chloride concentration. The $E_{\text {corr }}$ values in AAS mortars with chloride concentrations as high as $8 \mathrm{wt}$.\% remained as low as those observed in mortars containing no chloride [41]. Similar observations were made by Criado et al. [42] for steel-reinforced AAS, where immersion of mortar specimens in alkaline solutions with and without chloride made no difference to the measured $E_{\text {corr }}$ values, which remained around $-0.60 \mathrm{~V}$ vs $\mathrm{Ag} / \mathrm{AgCl}$. Studies of exposure of steel to simulated pore solutions representing AAS $[42,46]$ also indicate that chloride does not have an observable effect on $E_{\text {corr }}$.

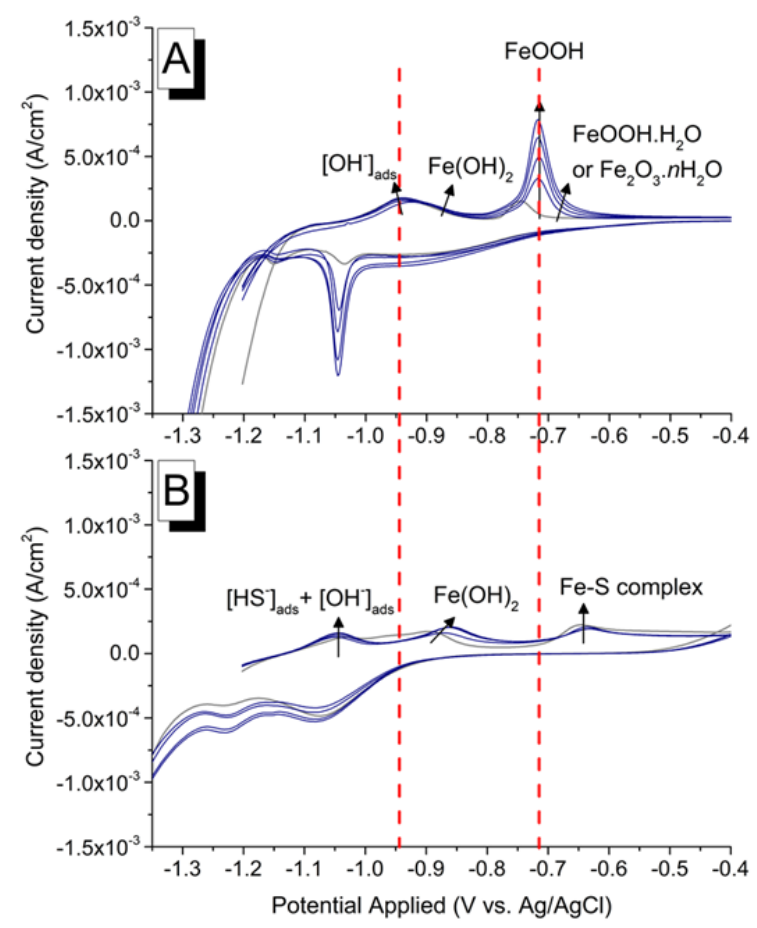

Figure 3. Cyclic voltammograms for steel exposed to aqueous solutions of (A) $0.80 \mathrm{M} \mathrm{OH}^{-}$(adapted from [10]), and (B) $0.80 \mathrm{M} \mathrm{OH}^{-}$ and $0.45 \mathrm{M} \mathrm{HS}^{-}$. Full experimental details are in [10]. Cyclic voltammetry scans are shown in part only; the hydrogen evolution regime, $-1.50 \mathrm{~V}$ to $-1.20 \mathrm{~V}$, is removed to ensure clarity. The grey line represents the first scan and the blue lines represent subsequent scans 2 to 5 . Here it is important to note that the first scan (grey line) would be the most representative of the anodic reactions occurring in sulfide-containing solutions as the anodic limit set in these experiments was $0.65 \mathrm{~V}$ (above oxygen evolution) which would result in the oxidation of reduced sulfur species. The red dashed lines indicate changes in the anodic reactions occurring at the solution/steel interface.

Holloway and Sykes [41] suggested that the oxidation of $\mathrm{HS}^{-}$ to elemental sulfur and its precipitation on the passive film play a major role in inhibiting pitting corrosion in AAS. However, in a different study [42] the $E_{\text {corr }}$ was observed to remain at around $-0.60 \mathrm{~V}$ vs. $\mathrm{Ag} / \mathrm{AgCl}$ for the full duration of chloride exposure, where the oxidation of $\mathrm{HS}^{-}$to elemental $\mathrm{S}$ would not be possible. A recent study conducted by some of the authors of this letter, using X-ray photoelectron spectroscopy (XPS) to analyse steel exposed to pore solutions representative of AAS (Fig.4), provides irrefutable evidence that the surface film contained sulfur only in the form of Fe-S complexes. Anodic polarisation curves obtained for mild steel in simulated pore solutions of AAS [47] also 
showed that the deposition of elemental sulfur occurs at a much higher potential, around $-0.05 \mathrm{~V}$ vs. $\mathrm{Ag} / \mathrm{AgCl}$. Therefore, elemental sulfur could play a role in inhibiting pitting corrosion only if sufficient oxygen is available at the $\mathrm{SCl}$.

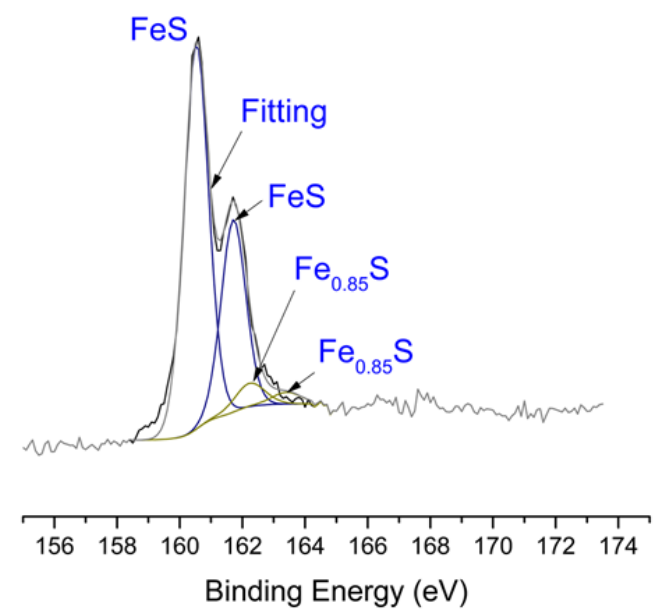

Figure 4. Sulfur XPS spectra obtained from the surface of steel reinforcement exposed to simulated AAS pore solution $\left(0.80 \mathrm{M} \mathrm{OH}^{-}\right.$ and $0.45 \mathrm{M} \mathrm{HS}^{-}$) stored under vacuum for 28 days. No deposition of elemental sulfur can be observed.

Higher corrosion rates [48], higher $i_{\text {corr }}$ and lower $R_{p}$ values $[42,49]$ have been reported for steel-reinforced AAS exposed to chloride solutions in comparison to those observed in PC. However, visual examination of the steel rebars in each of these studies found that the extent of corrosion for steel embedded in AAS was much lower than those in PC, for instance, no evidence of corrosion was observed by Criado et al. [42], Fig.5, which contrasts strongly with the electrochemical observations. The high $i_{\text {corr }}$ and low $R_{p}$ values are therefore likely to be related to the aqueous chemistry of the pore solution at the $\mathrm{SCl}$, not necessarily the actual corrosion resistance of the steel. In particular, these values correspond mainly to the oxidation of the $\mathrm{HS}^{-}$species in the pore solution (and not to the oxidation/reduction couple of $\mathrm{Fe} / \mathrm{Fe}^{2+}$ ), which takes place because of the potential imposed in the electrochemical test procedure used to determine these parameters.

In a study where steel was exposed to alkaline sulfidecontaining solutions [47], the onset of pitting and the chloride 'threshold' value were shown to depend on the concentration of sulfide as well as the time of exposure. Solutions representing the pore solution chemistry of AAS $\left(0.80 \mathrm{M} \mathrm{OH}^{-}+0.45 \mathrm{M} \mathrm{HS}^{-}\right)$did not induce any pitting in the entire 28-day duration of testing [47]. This behaviour can be explained by the role of $\mathrm{HS}^{-}$in altering the surface film, as well as in restricting the cathodic reduction of oxygen at the solution/steel interface. Therefore, even though passivation of steel by an iron oxide film is not seen in AAS, the formation of a macro-cell or chloride-induced pitting is inhibited until the concentration of dissolved oxygen at the $\mathrm{SCl}$ is low. In the case of AAMs with a reducing environment such as AAS, the role of $\mathrm{HS}^{-}$at the $\mathrm{SCl}$ is of significant importance. The high concentration of $\mathrm{HS}^{-}$in the pore solution not only creates a highly reducing environment around the $\mathrm{SCl}$ and hinders the development of passive iron oxide film (and creates a different 'surface' film consisting of mackinawite), but also restricts the cathodic reduction of oxygen and the formation of a macro-cell. The high $i_{\text {corr }}$ values generally observed for AAS are predominantly due to the loss of electrons from $\mathrm{HS}^{-}$in the aqueous environment, and therefore, leading to misrepresentative conclusions on the corrosion resistance of the steel reinforcement if electrochemical test results are interpreted from the assumption that all redox processes taking place in the material involve the steel itself.

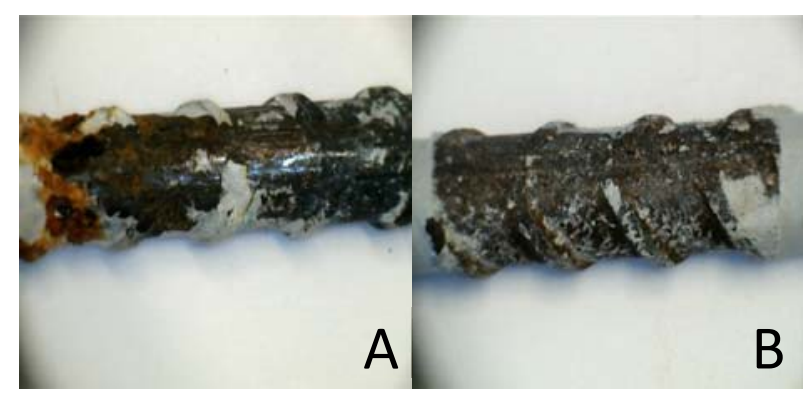

Figure 5. Steel reinforcing bars extracted from (A) PC and (B) AAS mortars, each exposed to $1 \mathrm{M} \mathrm{NaOH}$ solution containing $3.5 \% \mathrm{NaCl}$ for 270 days [42]. Steel embedded in AAS mortars did not exhibit any corrosion.

As for oxidising AAMs, the usage of classifications or recommendations developed and validated for steelreinforced PC concretes $[27,28]$ to characterise the passive and active states in steel-reinforced AAS would not yield accurate representations of the actual conditions prevailing at the $\mathrm{SCl}$.

\section{General Remarks}

Given the various aqueous environments that can be encountered at the $\mathrm{SCl}$ of AAMs, and the strong influence of the presence or absence of reducing elements in the pore solution (depending on the nature of the precursor used for production of AAMs) on the mechanisms of passivation and the onset of pitting, AAMs need to be classified on the basis of internal redox conditions when considering durability in chloride-rich environments, as illustrated in Fig.6.

In the light of such major differences in the mechanisms of passivation and corrosion between various steel-reinforced AAMs and PC, analysis of electrochemical properties through classifications or standards recommended for PC would be misleading in the case of AAMs. Instead, the influence of the chemistry of various AAMs on the steel reinforcement and the $\mathrm{SCl}$ needs to be studied in greater detail, and a larger database of experimental results is required to accurately characterise the electrochemical behaviour of the steel reinforcement in these binders. 


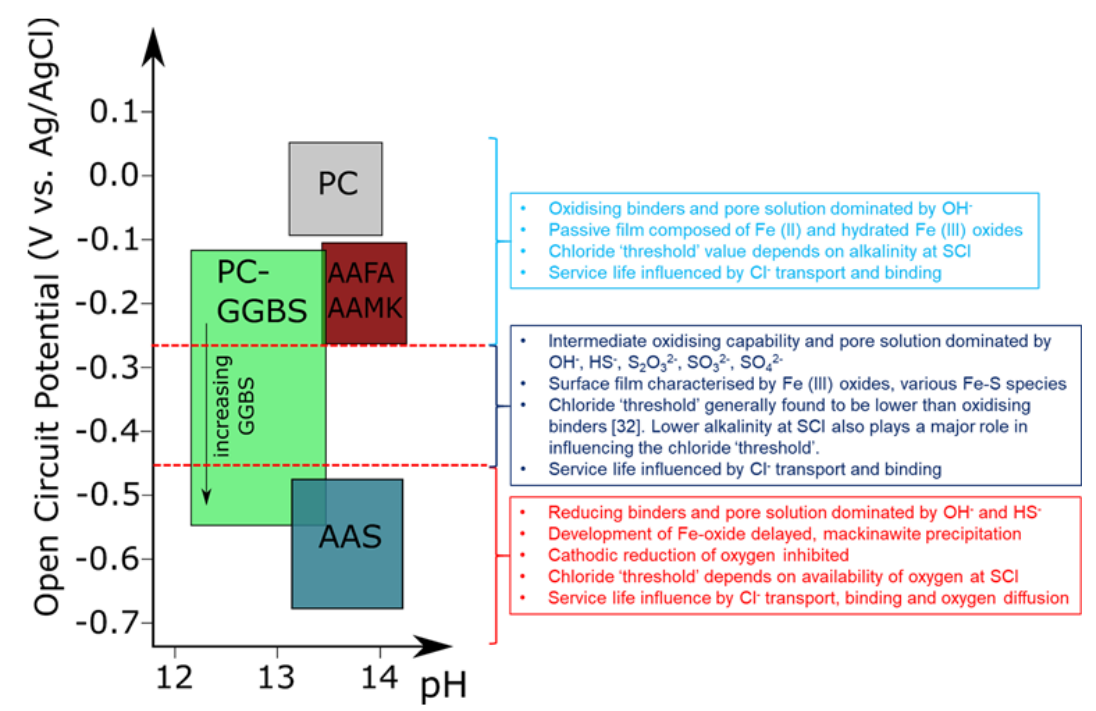

Figure 6. Overview of the classification of cements, particularly of AAMs, based on internal redox conditions prior to chloride ingress, and the parameters influencing the onset of steel pitting and the service-life of these binders. AAFA = alkali-activated fly ashes, AAMK $=$ alkali-activated metakaolin.

\section{Acknowledgments}

This research was funded by the European Research Council under the European Union's Seventh Framework Programme (FP7/2007-2013) / ERC Grant Agreement \#335928 (GeopolyConc), and by the Federal Ministry for Economic Affairs and Energy via the Industrial Collective Research (IGF) programme of the AiF / IGF project $18910 \mathrm{~N}$ of the GFKORR e.V.

\section{References}

[1] J. L. Provis, Geopolymers and other alkali activated materials: why, how, and what? Mater Struct (2013) 47: 11-25. https://doi.org/10.1617/s11527-013-0211-5

[2] S. A. Bernal, Advances in near-neutral salts activation of blast furnace slags. RILEM Tech Lett (2016) 1: 39-44. https://doi.org/10.21809/rilemtechlett.2016.8

[3] J. L. Provis, A. Palomo, C. Shi, Advances in understanding alkaliactivated materials. Cem Concr Res (2015) 78: 110-125. https://doi.org/10.1016/j.cemconres.2015.04.013

[4] A. Fernández-Jiménez, A. Palomo, Composition and microstructure of alkali activated fly ash binder: Effect of the activator. Cem Concr Res (2005) 35: 1984-1992. https://doi.org/10.1016/j.cemconres.2005.03.003

[5] C. Li, H. Sun, L. Li, A review: The comparison between alkaliactivated slag $(\mathrm{Si}+\mathrm{Ca})$ and metakaolin $(\mathrm{Si}+\mathrm{Al})$ cements. Cem Concr Res (2010) 40: 1341-1349.

https://doi.org/10.1016/i.cemconres.2010.03.020

[6] C. Shi, A. Fernández-Jiménez, A. Palomo, New cements for the 21st century: The pursuit of an alternative to Portland cement. Cem Concr Res (2011) 41: 750-763. https://doi.org/10.1016/i.cemconres.2011.03.016

[7] E. M. Gartner, D. E. Macphee, A physico-chemical basis for novel cementitious binders, Cem Concr Res (2011) 41: 736-749. https://doi.org/10.1016/j.cemconres.2011.03.006

[8] R. J. Flatt, N. Roussel, C. R. Cheeseman, Concrete: An eco material that needs to be improved. J Eur Ceram Soc (2012) 32: 2787-2798. https://doi.org/10.1016/i.jeurceramsoc.2011.11.012

[9] S. A. Bernal, R. San Nicolas, J. L. Provis, R. Mejía de Gutiérrez, J.S.J. van Deventer, Natural carbonation of aged alkali-activated slag concretes. Mater Struct (2014) 47: 693-707. https://doi.org/10.1617/s11527-013-0089-2
[10] S. Mundra, M. Criado, S. A. Bernal, J. L. Provis, Chloride-induced corrosion of steel rebars in simulated pore solutions of alkaliactivated concretes. Cem Concr Res (2017) 100: 385-397. https://doi.org/10.1016/j.cemconres.2017.08.006

[11] R. Pouhet, M. Cyr, Carbonation in the pore solution of metakaolinbased geopolymer. Cem Concr Res (2016) 88: 227-235. https://doi.org/10.1016/j.cemconres.2016.05.008

[12] K. Tuutti, Corrosion of steel in concrete. Swedish Cement and Concrete Research Institute, Stockholm, 1982.

[13] I. Ismail, S.A. Bernal, J. L. Provis, R. San Nicolas, D. G. Brice, A. R. Kilcullen, S. Hamdan, J. S. J. van Deventer, Influence of fly ash on the water and chloride permeability of alkali-activated slag mortars and concretes. Constr Build Mater (2013) 48: 1187-1201. https://doi.org/10.1016/i.conbuildmat.2013.07.106

[14] J. L. Provis, R. J. Myers, C. E. White, V. Rose, J. S. J. Van Deventer, Xray microtomography shows pore structure and tortuosity in alkaliactivated binders. Cem Concr Res (2012) 42: 855-864. https://doi.org/10.1016/j.cemconres.2012.03.004

[15] U. Angst, B. Elsener, C. K. Larsen, $\varnothing$. Vennesland, Critical chloride content in reinforced concrete - A review. Cem Concr Res (2009) 39: 1122-1138. https://doi.org/10.1016/i.cemconres.2009.08.006

[16] R. R. Lloyd, J. L. Provis, J. S. J. van Deventer, Pore solution composition and alkali diffusion in inorganic polymer cement. Cem Concr Res (2010) 40: 1386-1392. https://doi.org/10.1016/i.cemconres.2010.04.008

[17] P. Duxson, G. C. Lukey, F. Separovic, J. S. J. Van Deventer, Effect of alkali cations on aluminum incorporation in geopolymeric gels. Ind Eng Chem Res (2005) 44: 832-839. https://doi.org/10.1021/ie0494216

[18] J. M. Miranda, A. Fernández-Jiménez, J. A. González, A. Palomo, Corrosion resistance in activated fly ash mortars. Cem Concr Res (2005) 35: 1210-1217. https://doi.org/10.1016/j.cemconres.2004.07.030

[19] A. Fernández-Jiménez, J. M. Miranda, J. A. González, A. Palomo, Steel passive state stability in activated fly ashes. Mater Construcción (2010) 60: 51-65. https://doi.org/10.3989/mc.2010.53909

[20] D. M. Bastidas, A. Fernández-Jiménez, A. Palomo, J. A. González, A study on the passive state stability of steel embedded in activated fly ash mortars. Corros Sci (2008) 50: 1058-1065. https://doi.org/10.1016/j.corsci.2007.11.016

[21] C. Monticelli, M.E. Natali, A. Balbo, C. Chiavari, F. Zanotto, S. Manzi, M.C. Bignozzi, Corrosion behavior of steel in alkali-activated fly ash mortars in the light of their microstructural, mechanical and chemical characterization. Cem Concr Res (2016) 80: 60-68. https://doi.org/10.1016/i.cemconres.2015.11.001

[22] P. Hlaváček, S. Reinemann, G. J. G. Gluth, M. Rünger, G. Ebell, J. Mietz, H. -C. Kühne, Durability-related properties of geopolymer 
mortars. in: 6th Int. Conf. Non-Traditional Cem. Concr., Brno, Czech Republic, 2017.

[23] M. Babaee, A. Castel, Chloride-induced corrosion of reinforcement in low-calcium fly ash-based geopolymer concrete. Cem Concr Res (2016) 88: 96-107.

https://doi.org/10.1016/j.cemconres.2016.05.012

[24] K. Kupwade-Patil, E. N. Allouche, Examination of chloride-induced corrosion in reinforced geopolymer concretes. J Mater Civ Eng (2013) 25: 1465-1476. https://doi.org/10.1061/(ASCE)MT.1943-5533.0000672

[25] M. Criado, D. M. Bastidas, S. Fajardo, A. Fernández-Jiménez, J. M. Bastidas, Corrosion behaviour of a new low-nickel stainless steel embedded in activated fly ash mortars. Cem Concr Compos (2011) 33: 644-652. https://doi.org/10.1016/j.cemconcomp.2011.03.014

[26] C. Andrade, J. A. González, Quantitative measurements of corrosion rate of reinforcing steels embedded in concrete using polarization resistance measurements. Mater Corros (1978) 29: 515-519. https://doi.org/10.1002/maco.19780290804

[27] ASTM C876-15, Standard Test Method for Corrosion Potentials of Uncoated Reinforcing Steel in Concrete. ASTM International, 2015.

[28] C. Andrade, M. C. Alonso, J. A. González, An initial effort to use the corrosion rate measurements for estimating rebar durability, in: N. Berke, V. Chaker, D. Whiting (Eds.). Corros. Rates Steel Concr., STP25013S, ASTM International, West Conshohocken, PA, 1990: pp. 29-37. https://doi.org/10.1520/STP25013S

[29] A. Vollpracht, B. Lothenbach, R. Snellings, J. Haufe, The pore solution of blended cements: a review. Mater Struct (2016) 49: 3341-3367. https://doi.org/10.1617/s11527-015-0724-1

[30] M. J. Angus, F. P. Glasser, The chemical environment in cement matrices, in: MRS Proc., Cambridge University Press, 1985: pp. 547556. https://doi.org/10.1557/PROC-50-547

[31] B. Lothenbach, G. Le Saout, M. Ben Haha, R. Figi, E. Wieland, Hydration of a low-alkali CEM III/B-SiO ${ }_{2}$ cement (LAC). Cem Concr Res (2012) 42: 410-423. https://doi.org/10.1016/j.cemconres.2011.11.008

[32] A. Scott, M. G. Alexander, Effect of supplementary cementitious materials (binder type) on the pore solution chemistry and the corrosion of steel in alkaline environments. Cem Concr Res (2016) 89: 45-55. https://doi.org/10.1016/j.cemconres.2016.08.007

[33] F. P. Glasser, K. Luke, M. J. Angus, Modification of cement pore fluid compositions by pozzolanic additives. Cem Concr Res (1988) 18: 165-178. https://doi.org/10.1016/0008-8846(88)90001-4

[34] R. J. Myers, S. A. Bernal, J. L. Provis, Phase diagrams for alkaliactivated slag binders. Cem Concr Res (2017) 95: 30-38. https://doi.org/10.1016/j.cemconres.2017.02.006

[35] J. L. Provis, S. A. Bernal, Geopolymers and related alkali-activated materials. Annu Rev Mater Res (2014) 44: 299-327. https://doi.org/10.1146/annurev-matsci-070813-113515

[36] S. A. Bernal, R. San Nicolas, R. J. Myers, R. Mejía De Gutiérrez, F. Puertas, J. S. J. Van Deventer, J. L. Provis, MgO content of slag controls phase evolution and structural changes induced by accelerated carbonation in alkali-activated binders. Cem Concr Res (2014) 57: 33-43. https://doi.org/10.1016/i.cemconres.2013.12.003

[37] M. Chaouche, X.X. Gao, M. Cyr, M. Cotte, L. Frouin, On the origin of the blue/green color of blast-furnace slag-based materials: Sulfur Kedge XANES investigation. J Am Ceram Soc (2017) 100: 1707-1716. https://doi.org/10.1111/jace.14670

[38] A. Gruskovnjak, B. Lothenbach, L. Holzer, R. Figi, F. Winnefeld, Hydration of alkali-activated slag: Comparison with ordinary Portland cement. Adv Cem Res (2006) 18: 119-128. https://doi.org/10.1680/adcr.2006.18.3.119

[39] R. J. Myers, S. A. Bernal, J. L. Provis, A thermodynamic model for C(N-)A-S-H gel: CNASH_ss. Derivation and validation. Cem Concr Res (2014) 66: 27-47. https://doi.org/10.1016/j.cemconres.2014.07.005

[40] K. Y. Chen, J. C. Morris, Kinetics of oxidation of aqueous sulfide by O2. Environ Sci Technol (1972) 6: 529-537. https://doi.org/10.1021/es60065a008

[41] M. Holloway, J. M. Sykes, Studies of the corrosion of mild steel in alkali-activated slag cement mortars with sodium chloride admixtures by a galvanostatic pulse method. Corros Sci (2005) 47: 3097-3110. https://doi.org/10.1016/i.corsci.2005.05.035

[42] M. Criado, S. Mundra, S. A. Bernal, J. L. Provis, A study on the passive state stability of steel embedded in alkali activated slag mortars. in: 14th Int. Conf. Durab. Build. Mater. Components (XIV DBMC)., Ghent, Belgium, 2017.
[43] R. C. Salvarezza, H. A. Videla, A. J. Arvia, The electrodissolution and passivation of mild steel in alkaline sulphide solutions. Corros Sci (1982) 22: 815-829. https://doi.org/10.1016/0010-938X(82)90078-6

[44] D. W. Shoesmith, M. G. Bailey, B. Ikeda, Electrochemical formation of mackinawite in alkaline sulphide solutions. Electrochim Acta (1978) 23: 1329-1339. https://doi.org/10.1016/0013-4686(78)80013-9

[45] D. W. Shoesmith, P. Taylor, M. G. Bailey, B. Ikeda, Electrochemical behaviour of iron in alkaline sulphide solutions. Electrochim Acta (1978) 23: 903-916. https://doi.org/10.1016/0013-4686(78)87014-5

[46] S. Mundra, M. Criado, S. A. Bernal, J. L. Provis, Breakdown of the passivity of steel in simulated alkali-activated concrete pore solutions. in: 36th Cem. Concr. Sci. Conf., Cardiff, Wales, 2016.

[47] S. Mundra, S. A. Bernal, J. L. Provis, Corrosion initiation of steel reinforcement in simulated alkali-activated slag pore solutions. in: 1st Int. Conf. Constr. Mater. Sustain. Futur., Zadar, Croatia, 2017.

[48] Q. Ma, S. V. Nanukuttan, P. A. M. Basheer, Y. Bai, C. Yang, Chloride transport and the resulting corrosion of steel bars in alkali activated slag concretes. Mater Struct (2015) 49: 3663-3677. https://doi.org/10.1617/s11527-015-0747-7

[49] C. Tennakoon, A. Shayan, J. G. Sanjayan, A. Xu, Chloride ingress and steel corrosion in geopolymer concrete based on long term tests. Mater Des (2017) 116: 287-299.

https://doi.org/10.1016/j.matdes.2016.12.030 